doi: 10.29359/BJHPA.13.Spec.Iss1.13

\title{
Olympism and Himalaism
}

\author{
Andrzej Pawłucki \\ University School of Physical Education and in Wroclaw, Poland
}

\section{abstract}

Background: As the title makes it clear, this article concerns the anthropological issue involving the figures of an Olympic athlete and a Himalayan climber. On a broader, philosophical level, I consider and explain the differences between Olympism and Himalaism, as well as the predecessor of Himalaism, Alpinism. The study aims to explain the reason for the origin of Olympism as a social movement independent of Himalaism. To understand why Olympism and Himalaism should be considered separately, one must go back to the dawn of the two modern events: "visiting the mountains" and "populating the stadiums".

Material and methods:

The philosophical method was used in the consideration. The two events never became a unity of being in the anthroposphere, nor a unity of meaning in the axiosphere. The distinctness of each is explained by the metaphysical anthropic principle. Olympism is governed by the strong anthropic principle of the "zone of life", while Himalaism is governed by the weak anthropic principle of the "zone of death". The anthropic principle of the Himalayas states that the mountains have those exact properties that enable a person to get to know themselves as an antagonist - a warrior and ultimately a conqueror. For people the initial and boundary conditions of the Himalayas, which are marked by the "zone of death", are the verge of the anthroposphere in their expansive transgression. Olympism with its anthropically strong 'zone of life' is something different. Only "at" the foot of the mountain can one set up a stadium, engage in an agonistic relationship and get to know oneself as the winner of a good competition or even, if historically necessary, the redeemer of the moral evil in the antagonism of war. In this sense, Olympism becomes a philosophy of moral consolation.

Results \& Conclusions: The result of the study shows that the Himalayan climber does not participate in the universe of the humanistic culture of the Olympics. Sport climbing to be introduced into the Games of the XXXII Olympics, in 2021 will remind us of this self-referencial existence at the edges of the anthroposphere, as well as the predecessor, of Himalaism, Alpinism.

Key words: philosophy of sport, mountain climbing, Himalaism, Olympism, Olympic Games.

\section{article details}

Article statistics: Word count: 8,589; Tables: 0; Figures: 0; References: 16

Received: June 2021; Accepted: October 2021; Published: November 2021

Full-text PDF: http://www.balticsportscience.com

Copyright @ Gdansk University of Physical Education and Sport, Poland

Indexation: Celdes, Clarivate Analytics Emerging Sources Citation Index (ESCI), CNKI Scholar (China National Knowledge Infrastructure), CNPIEC, DOAJ, EBSCO - Central \& Eastern European Academic Source, EBSCO - SPORTDiscus, EBSCO Discovery Service, Google Scholar, Index Copernicus, J-Gate, Naviga (Softweco, Primo Central (ExLibris), ProQuest - Family Health, ProQuest - Health \& Medical Complete, ProQuest - Illustrata: Health Sciences, ProQuest Nursing \& Allied Health Source, Summon (Serials Solutions/ProQuest, TDOne (TDNet), Ulrich's Periodicals Directory/ ulrichsweb, WorldCat (OCLC)

Funding: This research received no specific grant from any funding agency in the public, commercial, or not-for-profit sectors.

Conflict of interests: Author has declared that no competing interest exists. Andrzej Pawłucki; University School of Physical Education in Wrocław; email: andrzej.pawlucki@awf.wroc.pl

This is an open access article distributed under the terms of the Creative Commons Attribution-Non-Commercial-NoDerivatives 4.0 International (https://creativecommons.org/licenses/by-nc-nd/4.0/), which permits use, distribution, and reproduction in any medium, provided the original work is properly cited, the use is non-commercial and is otherwise in compliance with the license. 


\section{INTRODUCTION}

In 1894, two years before the first Olympic Games of the modern era, the International Olympic Committee decided that a prize would be awarded for the "most interestingly executed" feat of mountaineering [1]. ${ }^{1}$ This was decided by Pierre de Coubertin, followed by agreement from the other members of the Committee. The conqueror of the mountain would be equated with the Olympian of the sports stadium.

In ancient times, no one spoke of mountain climbing as a sports competition. Not because the mountains of the Olympus are several hundred kilometers north of the sanctuary in Olympia (where is Thessaly, and where is Elida?), but because the mere achievement of reaching the summit of the mountain by a mortal was regarded as usurping the abode of Zeus - the father of gods and men.

Whoever headed for the abode of the gods was knocked down from the mountain. Mountains were the home of the gods everywhere: from the Andes to the Himalayas. For the Hindus, Hima'calu was the abode of the gods, and for the Proto-Greeks Helicon was the birthplace of the gods. It was here that the gods came into their power and here that one pantheon deprived another of its power, so that, for the Achaeans - as Hesiod argued in The Birth of the Gods - from the world of the gods emerged heroes who, together with mortals, were subject to the power of Zeus [2].

There would have been no Games in Olympia had it not been for the sanctity of the place, where first the greatness of Kronos, ruler of the universe, was glorified, followed by Zeus, after his father was thrown from Olympus [2]2. Hercules, son of Zeus, worshipped his father's memory at the site of the temple, where the stadium also commemorated the greatness of the deity. However, the first Games of the modern era held in Athens were not called "Athenian" but specifically "Olympic", which meant that they invoked the Spirit of Father Zeus [3] ${ }^{3}$ and praised his divinity rather than Athens - as in the days of the tyrant Pisistratus, when the Panathenaic Games celebrated the greatness of this Olympian deity of the pantheon.

Neither Zeus's Olympus, nor Apollo's Parnassus and Helicon "wanted" to be conquered in an agonistic style. Conquering the mountain was not part of the programme of the Panhellenic Games, and the competitions themselves resembled or imitated the skills of warriors: running, throwing (javelin and discus), wrestling and boxing. Fights between riders took place in the hippodrome next to the stadium, and this also alluded to the battlefields of war. In Olympia, everything referred to war or heralded war - for example the use of trumpeters and heralds or runners dressed in hoplite armour.

Hercules who decided to commemorate the greatness of his father by organising the Games in his honour at Olympia both had to, and must have wanted himself to compete in wrestling or throwing competitions. He did not take part in a climbing race because there was no such a competition. However, as punishment, he had to take part in underground mountain climbing (the 12th labour of Hercules when, like a caver, he found himself on his way back from the underworld of Hades. A climbing ascent followed a descent through the cave; the descent had to be followed by a climbing ascent- somewhere in Argolis, where he dragged Cerberus to the surface and was set free.

1 "Qu'en outre, à l'occasion des Jeux Olympiques, un prix d'alpinisme soit attributeué à l'ascension la plus intéressante performie sur un point quelconque du globe, depuis le dernier concours".

2 The myth states that Kronos "was knocked down from Olympus by his son Zeus, who took power from him". The phrase "thrown off from Olympus" literally indicates a battle fought on top of a mountain, which ends with the opponent being thrown into an abyss. It may also indicate that Kronos - the most ancient deity - was deprived of his power in a battle fought at Elida, a temple site commemorated by the name Olympia - after the mountains of Olympus as the abode of the gods. Only then does it become understandable why Olympia is located in Elida, on the Peloponnese, and a small hill was named Kronious Hill, after Kronos - the god of the universe.

3 The author of the Olympic Hymn, Kostis Palamas, identified the "Immortal Spirit of Antiquity"with the "father figure of earth and heaven" [3]. 
A modern caver is an underground "wanderer", or a potholer with a sporting streak; after the caver descends, they have to climb on the way back up - something he or she has turned into a sport or competition with themselves in covering the route in as quick a time as possible in the style of a rock climber.

\section{CLIMBING AS CONQUERING A MOUNTAIN, VS, SPORT CLIMBING}

Rock climbers will participate in the Games of the XXXII Olympiad; not as "conquerors of the mountains" in general - since, informally they belong to the beggar caste of the HIMALAISTS $^{4}$ - but as institutionalised athletes, subject to the authority of the federation of sport climbing associations. ${ }^{5}$ Contrary to appearances, making sport climbing a new Olympic competition with three disciplines - bouldering, lead climbing and speed climbing - has nothing to do with the mountaineering climbing originally advocated by Pierre de Coubertin. The only thing in common is the word "climbing", and the feat is quite different, just as climbing a natural wall to reach the peak of a mountain is different from "climbing" a ladder in order to reach its top rung as quickly as possible; one action is so different from the other. The first one may be lethal", and the other one as ridiculous as a "tug-ofwar" by circus strongmen or breakdancing street performers. The Olympic accolade was to be awarded to a mountaineering conqueror, which was to be related to a long-term feat. And only in this sense did the feat of mountaineering become an out-of-stadium Olympic competition - regardless of the name of the mountain range in which it was accomplished. This was the case with the brothers Toni and Franz Schmidt, after their ascent of the north face of the Matterhorn-Nordwand in the Alps (4477 m; 1931) or the record-breaking ascent by a woman, Hettie Dyhrenfurth, of Sia Kangri in the Karakorum (7422 m; 1934), when the Olympic medal was awarded for "conquering a mountain" - even if only to a height no one had previously reached (Dyhrenfurth) - and not for the "act of climbing" itself - regardless of the mountain location. It follows that the "sport climber" competitions introduced into the Olympic stadium community are not in the same category as "mountain climbers" - although they may originate from the latter community. In general, both the social movements - of alpine-himalayan mountaineering and Olympic sports are independent of each other, despite the introduction of the "sport climbing" competition into the Olympic programme.

Sport climbers are, therefore, nominally neither alpine nor himalayan climbers. They have only, in a sense, become representatives of the community of MOUNTAIN CONQUERORS, since the very act of speed climbing natural rock routes has been made a sport. A natural Alpine or Himalayan climber could, if they wanted to take part in sport, enter competitions on natural rock - granting themselves the identity of agonist and dispelling their inherent identity as a mountain antagonist (below). The act of climbing is contained in the rule of conquering the mountain by a warrior, and climbing as an eminently ancillary activity can acquire the status of a self-intentional act when the competition takes place on identical parallel routes - made artificial in every respect and set in a stadium environment. By reducing the act of climbing to a wall (a wall which, moreover, imitates a "piece" of a natural mountain in its conventional appearance) to a simultaneous agon (parallel race) and placing this architectural construct in front of an audience of reviewers (judges and

4 This is what I call modern extreme mountain climbers, who form expedition teams after soliciting funding from generous donors. The first mountain climbers in the age of romantic individualism supported themselves materially being wealthy and financially independent aristocrats. In a way, they fulfilled the expectations of Baron Pierre de Coubertin as amateurs of life, taking up sporting activities completely selflessly. Contemporary mountain climbers often have aristocratic origins, but they organize their non-climbing time with "beggars' donations"preceded by fundraising for future expeditions.

5 The national sport climbing associations report to the International Federation, established in 2007.

6 Ascending the most difficult peak of Gasherbrum IV at $2500 \mathrm{~m}$ was considered the most outstanding Himalayan feat of the 20th century. Speed climbing up a $15 \mathrm{~m}$ high artificial wall has nothing in common with mountain climbing, if, in drawing parallels, one wishes to consider climbing ropes and hooks as identifying props for both activities. The subjects of these actions are different in an anthropological-cultural sense, meaning that mountaineering belongs to the role of the "mountain climber" and speed climbing - to that of the "stadium winner".

By coincidence, only a Himalayan climber "descending" from the mountain at the precise moment could find themself in the Olympic stadium as a competitor - deprived of any chance of victory. In the same way, a sport climber could not claim the status of "conqueror of the mountain", of the Olympic stadium, if they do not radically change their training rules, not to mention the personal transformation, they would have to make in themselves. 
spectators), the reflected self of the performer of the competition task radically moves them towards their recreation as a stadium competitor. If a Himalayan climber (nominally an Alpine climber) came from a high-mountain expedition to a rock-climbing stadium, in which he or she would be forced to imitate themselves only in terms of hastily anchored bolts to race "whoever is first" - they would become the opposite identity from themselves - a competitor-winner (agon), and not a warrior-conqueror (antagon). The reverse is also true: a contemporary "sport climber" who operates in conditions of an artificial wall placed in a stadium auditorium, cannot belong to the community of "mountain conquerors" at the same time. Moreover, he or she might not be able to cope with the feat of mountain climbing, which is antagonistic by definition, that is, forcing the induction of a warrior mentality (absolutely individualistic).

However, a Himalayan climber, in the sense of a warlike conqueror of a mountain, is someone who has acquired the skill of climbing and has accepted the "provocation" of the mountain, challenging him or her to reach its peak by using climbing manoeuvres and techniques on the mountain's face. Reaching the summit is not about climbing a slope, it is just laborious pulling yourself up a wall of varying degrees of difficulty. A mountain is only truly conquered when the wall "indicated by it" is taken into account - as a surface insurmountable by a mortal. This is what Wojciech Kurtyka and Robert Schauer (1985) did when climbing Gasherbrum IV via the western wall route - the most difficult wall of all the mountains in the world and which was considered the greatest Himalayan achievement of the 20th century [4] .

Conquering a mountain implies climbing a mountain wall, which in itself is already conquering. As an extreme feat in the anthroposphere, this activity does not belong in a stadium. It is not, therefore, an Olympic feat - as Pierre de Coubertin envisioned it - and has never become one on a permanent basis. Despite the introduction of "sport climbing" to the Olympic programme, Himalaism is not an Olympic event.

The aim of this reflection is to explain the reason for the origin of Olympism as a social movement independent of Himalaism (formerly Alpine mountaineering) and to present the premises leading to the recognition of the philosophy of Olympism as a logos independent of Himalaism.

\section{THE OLYMPIC MOVEMENT AND THE HIMALAYAN MOVEMENT}

To understand why OLYMPISM and HIMALAISM should be considered separately, and why the figure of the Olympic athlete cannot be equated with that of the Himalayan climber, one must go back to the modern dawn of both events. Both social events constituted themselves as independent tendencies and never became a unity of being in the anthroposphere, nor a unity of meaning in the axiosphere.

The dissimilarity of both terms is explained by the metaphysical anthropic principle. Olympism is governed by the strong anthropic principle of the "zone of life" and Himalaism by the weak anthropic principle of the "zone of death". If mountains as high as the Himalayan range did not exist, the problem of the disconnection between the two tendencies could only be raised in a thought experiment in which one might as well consider OLYMPISM in a Martian version with Olympus Mons as the giant in the role of protagonist. The anthropic principle of the Himalayas states that the mountains have exactly the properties that enable people to get to know themselves as CONQUERORS. The initial and boundary conditions of the Himalayas, which are marked by the "zone of death", are the edge of the anthroposphere for people. The maximisation of the transgressive expansion towards the expansion of the anthroposphere ceases when mankind enters the "zone of death". The

7 It concerns the ascent of the west wall of Gasherbrum IV by Wojciech Kurtyka and Robert Schauer (1985). The climbers did not reach the summit of the mountain, yet their feat was considered the greatest achievement of Himalaism in the 20th century [4] 
laws of physics in the Himalayas make it possible for a human to exist as a CONQUEROR. The Himalayas "accept" mankind because for them they are the end of earthiness; they "accept" as if awaiting mankind's appearance. In other words, if it were not for the anthropic "benevolence" (however weak) of the Himalayas - a climber would not be able to climb to the mountain top and declare themselves a CONQUEROR.

As for Olympism, the strong anthropic principle applies to this social movement, which also takes the form of an extreme expression of human physicality. This principle confirms that in earthly nature fine tuning has been carried out, thanks to which a rational creature has appeared, recognizing the "zone of life" in the nature of the Earth. If it had not been for the fine tuning of nature, human life would not have appeared, and thus the epistemic subject would not have appeared - learning about itself and the meaning of its destiny. Olympism as a social movement takes place in the "zone of life". It is both symbolic praise and a real space for affirming the meaning of life in the love of friendship. In the ontological layer of its logos, it is the antithesis of the deadly field of war (created artificially out of the motives of hatred of the "death zone"). In this sense, Olympism is the antithesis of Himalayan mountaineering. Olympism brings peace to human relationships and leads to participation in the culture of friendship; it uses the "gate of life" to affirm life. Himalaism, on the other hand, enters the "gate of death" and is at best an extra-symbolic (literal) desperate drive towards the "gate to life" in the culture of individualistic hedonism in the version of adventure escapism.

The Himalaism mountaineering movement was a consequence of British colonial aspirations, which, as we know, existed for military purposes. The goal of climbing in mountaineering was not taken into account by the first climbers, despite the fact that at the same time in the history of climbing, the mountaineering activities of aristocrats were leading to the dynamic development of the climbing movement for reasons of entertainment. British "servants of maps", who in the nineteenth century carried out triangulation, cartographic, topographic, geodetic, and - in general - geographic works were of great importance in the development of himalaism in the colonial era. They included George Everest and Andrew Waugh, who, after triangulating Kangchenjunga, Summit XV, "raised" the Himalayas to the height of at least 8,588 $\mathrm{m}$ (1847). Himalaism started in the Alps in the sense that aristocrats "from the European playground" moved to the Karakoram and became interested in Nanga Parbat, where they were the first known to have died. From the very beginning, Himalaism had all the features of romanticism in the community of British aristocrats who wanted - as Mummery said - "to travel, measure and research as much as possible [5]". ${ }^{8}$ Himalaism took place far from Europe, and, at the same time as Albert Mummery and three others the first victims of climbing in the Himalayas - died in 1895 on Nanga Parbat the Olympic stadium in Athens was made ready.

The Olympic movement was initiated by social reformers, romantic aristocrats - opponents of war. Olympism could bring peace, as the Greeks once did. In this sense, it was to be a messianic, or movement of salvation. Pierre de Coubertin, who deplored the failures of the peoples of civilised Europe, and who was particularly pained by the failure of his own nation, announced a plan for the renewal of "all mankind" through national teams which he invited to participate in the modern Olympics [6]. ${ }^{9}$ He presented his plan for the physical, moral and intellectual revival of the nations in a "symphony for the salvation of mankind" never finished - calling it Neoolimpism and Neoencyclopedism [8]. He never completed it, only getting halfway to the utopia of the renewal of the nations of all mankind; its physical, moral and intellectual renewal. For Pierre de Coubertin, Olympism was the pedagogy of sport, in which the acts of sport assumed the improvement in physicality and imposed

\footnotetext{
8 The history of the conquest of the Himalayas is presented by Maurice Isserman and Stewart Weaver [5].

$9 \mathrm{I}$ am leaving out the details of the history of modern Olympism, well described in the history of many historians. In this essay, I only use the data that has a premise in the formulated "law of the Olympic peace" [7].
} 
a moral formation according to the ethos of chivalrous nobility. And since the Games were to become a meeting place for nations, it was possible to reconcile them - on the basis of "mutual respect"- in the stadium. A stadium could provide peace, because you had to get to know each other first to respect each other and this is not a utopia: "to require from nations to love one another would be childish" [6]. ${ }^{10}$

Nowadays, no one knows why the Ancient Games were held every four years. The creator of the Modern Games explained that they were a celebration of a reborn society; because life is reborn every four years. The four-year cycle of the Olympics symbolizes a reviving life, which should be solemnly announced to mankind and included in the family celebration of Youth Day.

Olympism pedagogy also assumed the general improvement in physicality as an indispensable rule. The Olympian receives social distinctions as one of all those who belong to the physical aristocracy of the gymnasion. Its author formulated the law of physical culture, in which he drew attention to the necessity of promoting the rule of physical renewal. Thus, not only in the stadium, but also in the public gymnasion, the physical potential of the societies of modernized humanity would be renewed.

Olympism, obviously, assumed the participation of athletes in chivalrous morality, and therefore aristocratic arete - in general - in accordance with the ethos of the nobility. Only noble aristos could live up to the ideal of moral nobility - the virtues of honesty and selflessness - desired in Olympic competition. Who, if not noble amateurs of life, would testify to the humanity contained in the competition of stadium life and who, if not Olympians - stadium winners - would show humanity the ways of moral salvation. Hence the belief of the Olympic utopian that since sports life allows you to remain faithful to yourself in integrity, then the other life of "all mankind"- imitating the art of Olympic sport - can endure disagreements, suspicion, prejudices and hostile attitudes. Was it not from this conviction that the saving thought of the Olympic pedagogue about "sport as a school of virtues" arose? Was it not from this belief held by many similar utopians - the idealistic disposition of a modernist against fin de siècle pessimists - that the salvation of humanity, which begins in the stadium must be supported by the stadium? The aristocrats - the restorers of mankind, were the instigators and executors of the work of restoration and earthly salvation, which was to be accomplished through participation in sport - "an invaluable" instrument for restoring and strengthening social peace" [6]. ${ }^{11}$ And although the first global war of the modern era abolished social peace - thereby putting all humanity affected by the atrocity into a state of doubt and despondency - nothing changed in the REPUBLIC OF OLYMPISM of the peoples of the world as postulated by Pierre de Coubertin. Despite the barbarity of the political leaders of the war and their obedient generals - the executors of the destruction of the enemy - the conviction of the proponent of participation in a culture of peace and in the life-giving power of the Olympic Games as "the spring festival of mankind to celebrate the next coming of human generations" (1936) did not diminish. De Coubertin had previously expressed these ideals solemnly and optimistically in the Olympic Letters to university students, and then in an appeal to all the young people of the world. In this he maintained his belief in the importance of the religion of sport as "an invaluable instrument for restoring and strengthening social peace" (1919), and the Olympic work as "a school of nobility and spiritual purity as well as endurance and physical energy" (1927).

It could be deduced from these pieces of the Olympic symphony - contained in essays, letters, proclamations, speeches and lectures, as well as poetic texts - that the very idea of

10 This moral realism was expressed by Pierre de Coubertin in a speech broadcast over the radio, one year before the Games of the 11 th Olympiad in Berlin [6].

11 Pierre de Coubertin also pinned his hopes on "university students as the most active hosts of the creators of this great work" - about whom he wrote in his "Olympic letters" of 1918-1919 [6]. 
the renewal of the peoples of "all mankind" in physical and moral terms was immense and global in scope, and that for the saving revalorisation of the human race, Pierre de Coubertin needed an Olympic stadium - occupied by an elite aristocracy of amateurs of life - and an egalitarian gymnasion, intended for the bodily formation of the young world community. This would arise in the proportions of five people capable of achieving astonishing feats would emerge from a hundred men devoted to physical culture (1935).

The intention to transform humanity contained in the philosophy of modern Olympism was as much messianic (in the sense of improbable) as it was impracticable (in the sense of the causal inadequacy of the instrumentality of the Olympic movement). The Olympic family of the first Modern Games could probably have done a lot to increase the spirit of chivalry and improve the physical capacity of their "relatives" - especially since it received the institutional guarantees of national Committees, and ultimately the affirmation of community good by the International Olympic Committe (IOC). However the effectiveness of its influence, as in all symbolic and conceptual works (such as religion and art), was suspended, dispersed or even destroyed by "false prophets" - tyrants of authoritarian power. Pierre de Coubertin himself, as the eulogist of the Spirit of Olympism - which was expressed so beautifully and heartfelt, expressed in the Ode to Sport had to deal with them at the end of his life. Even he could not have foreseen that the executor of the work of the 11th Olympics would first turn the Olympic ideal into its opposite (replacing social love with hatred), and using the whole symbolic reality of the Olympic sacrum as an instrument in the military plan for the annihilation of those he defined as racially inferior humanity.

After the Second World War, Olympism justified constant praise, but, like any universal humanism - triggering aspirations in humanity - it could not be accepted except through legitimate realism. The promoters of the Olympic idea should continue the work of the moral and physical renewal of the nations of "the entire population", but with an awareness of the objectively possible (and theoretically probable) consequences of the scope of influence, as well as the causative limitations in establishing a culture of life. ${ }^{12}$ For this reason Olympism, as the face of ethical modernism in the second phase of the modern era, was becoming a realistic philosophy of moral consolation. The realistic Olympism that followed the totalitarianism of National Socialism and International Communism (still active "volcanoes" in the tyranny of freedom and equality of progress) had to justify the importance of its ideological aspirations - as a normative logical structure - with the premise of metaphysical reasoning. The emergence of Olympism as a philosophy of moral consolation is explained by the metaphysical principle of the constitution of possible being. Thanks to it, we understand why Olympism as a social event did not exist and could go no further. ${ }^{13}$

The existence of the Olympics came into being, though it did not have to. It became real, though it could have remained "for ever" in a state of potentiality. However, it did not arise from nothing, because before it was conceived, it was recognised as an entity of "inverted" moral reason (apparent good), manifested by acts of ontic evil. In order to better understand this dependence - of the being of possible Olympism on the actual being of war - it is necessary to refer to the metaphysical explanation of the nature of possible being. If we assume that possible being "is that which does not exist, but can exist in reality; which does not have existence, but can possess it; which does not belong to reality, but can belong to it" [7], it is precisely sport Olympism as a conceived being - at the same time opposing the reality of war - that corresponds to this relationship of conditioning. When it emerges realistically as a social movement of pacifists, manifesting symbolically moral aspirations towards fulfilment through brotherly love, it begins to oppose the militarists and the very object of thought of war itself. When an external cause is sought, which constitutes the being of Olympic sport, it could be concluded that if it were not for the real moral evil of

12 I mean here the Olympic athlete as a redeemer of the moral evil of war

13 I explain this relationship in the law of the Olympic peace [7]. 
acts of war, there would be no mental premise for contrasting it with the moral good in the sign-symbolic rule, and consequently establishing its physical representation.

The act of agonism in the stadium of peace could be conceived of as the reverse of the potentiality of being, for since the dawn of history its obverse has existed in reality: antagonism in the field of war. The being of Olympism was symbolically opposed to war, empowering the figure of the stadium agonist invented by charismatic moralists - placed in the conventional battlefield - to perform acts of unconditional respect for the dignity of the "fake opponent".

An act of moral good became possible because there was a subject of acts of moral evil. The Olympic Act towards true good could be, and in fact was, conceived by a subject opposing moral evil, because in reality there was a subject that denied the liberation of mankind in favour of their personal fulfillment in love. In the mind of the sports mind, judging the evil of militarists, the object of Olympism for peace (the physical potential of Olympism was evoked in it) the very subject of the agonistic relationship called to a redemptive act was born in its imagination. In terms of awakening Olympic agonism from the state of eternal potentiality, it was as if the inferior side of the image of humanity - shown as the obverse of shame - waited to be embossed on the reverse side of the pattern of its humanistic aspiration.

\section{THE HIMALAYAN CLIMBER AND THE OLYMPIC ATHLETE}

The result of comparing the participation of both extreme athletes in the Himalayan and Olympic movements can be as follows. Himalayan climbers conduct an experiment on themselves in the phase preceding the ascent of the mountain, which consists of submitting to perfecting asceticism according to the iron rule of bodily "anguish". As early as the initial phase, it is excluded from social, professional and personal relationships. The necessary condition of their life in both phases - preparation to conquer and the very conquest of the mountain - becomes the denial of their social condition. Even if they deny this and refuse to deny their social condition, the mountaineer must die socially if they want to become self-reliant individualists. Conquering mountains solo symbolises this individualism as their modus vivendi. Desocialization is an indispensable condition to achieve the task successfully. As soon as the climber moves from the alpine playground to Karakoram, and then to Everest in the Himalayas, he or she begins to work on themselves wearily like a naturalist might. He or she loses the features of a romantic individualist. Entering the "zone of death"; they do not want to die but expose themselves to death; they want a healthy body but lose their health. Nobody is as cruel to the body as a mountaineer. Not even a member of an enclosed religious order, who also first dies socially and then drives their body to necrosis and, in extreme cases, their life to death, which makes them similar to an antagonist who freezes to the bone. In the axiosphere, they do not present any signs-symbols that would somewhat explain their ideological nature, or at least explain it more clearly than at a banal level and declare the rationale of expansive transgression (I conquer the mountain because it is there). This can happen when he or she conquers a mountain. When Reinhold Messner did so, the only "flag" he carried was a handkerchief. The reason for his feat was himself, with the impoverished physicality of his entire body and the lost claritas of his face, beauty and health. The Himalayan climber works hard in mountain climbing teams - using the donations begged for to experience their adventure with death.

The Olympic athlete, as a winner in the stadium also experiments on him or herself, because the result of their deed is based on extraordinary physical strength developed through strenuous training. This - and only this - makes them similar to a Himalayan mountaineer. When entering the competition, they do not anticipate "dying"- just like a long-distance runner - they are appointed to participate in the community of life. The meaning of their 
action is inflicted upon them - as if they were a missionary of good news. Their axiosphere is full of the signs/symbols, of each of them, especially the anthem, the oath, the flag, the torch and, of course, the medal itself. When these are to the first, whomsoever reveals the aspirations of physical transgression to aim higher, faster and stronger (citius, altius, fortius) in the agon expresses the athlete's virtues of dignity.

If they are two such different actors of physical transgression: the individualistic Himalayan climber, who excludes himself from existence in the lowland community of life; and the Olympic athlete, who establishes relationships of friendship in the culture of life, then why did the forefathers of the Olympic movement want to see the antagonist - the mountain climber - in the family of sports agonism from the very first Games?

The antagonist cannot cope with the morality of the agonist, but neither do they want to be called into the sporting moral order. When activists invited mountain climbers back to the Olympic stadium they had not only forgotten the official position of the climbers' federation (In 1936, the mountaineers refused to integrate the movements - explaining that "a sporting mentality cannot be shared by mountaineers".), they had also forgotten that the mountaineers themselves turned their backs on Olympism when they refused to accept the Olympic Order (1988). ${ }^{14}$

Olympism and Himalaism are two different beings in the order of things as social realities, and in the order of cognition as logical realities as it is more or less methodologically advanced. It is possible to understand what their disconnectedness results from by explaining why a Himalayan climber is not an athlete. At the beginning of this metaphysical puzzle it should be noted that an athlete is an a-gonist and a Himalayan climber is an anta-gonist. What does this mean? An athlete takes part in a competition and a Himalayan climber in a fight; from this comes the notion that an athlete is a competitor who discovers that they are winners, and a Himalayan climber is a fighter who finds out that they are conquerors!

Few people notice (meaning within the logically flawed categorisations of sport) that sporting competitions take place in two related spheres:

a) a parallel agon (known as competition)

b) a non-parallel agon - reverse/opposite (called sham combat)

In the parallel agon, the athlete maximises action in order to physically differ from the competitor towards victory over him, without experiencing resistance on his part. Athletes are positioned side by side, not "against" each other. They cannot even touch or push each other.

In the non-parralel/reverse agon, the athlete of sham combat blocks the other by preventing him/her from completing the task, diminishing the efficiency of their skilled actions. The winner blocks the function but does not annihilate the subject. The winner only inhibits the constitutive activity of the opponent. For sham combat is not about "killing the opponent", but "weakening" them in a task constitutive to their identity. Sport combat does not presuppose killing the opponent. That is why non-parallel sports agonism is not ANTAGONISM.

"A reverse" agonist cannot strike a blow "below the belt" or break a bone. When a combat agonist athlete intends to kill a fellow competitor, they become murderers, and the "killing" relationship becomes a gladiatorial one. A sports stadium is not a gladiatorial coliseum. After the competition, one agonist becomes the winner and the other the loser - by no means the defeated (footballer, tennis player, boxer). In both cases of agonistic relationships, the 
sporting primus recognises him or herself as the WINNER. A boxer or a tennis player does not say that he is a CONQUEROR.

A different thing happens in the life of a Himalayan climber who establishes a relationship of struggle for life with an unequal opponent. A Himalayan climber is not an athlete, but not only because he or she is not an agonist. A climber always develops an antagonistic relationship - by assumption ending with their annihilation. They take part in an unequal antagonistic relationship, and yet take up the challenge of a personified opponent in the fight, in other words, a mountain "striving" to kill them. Antagon - the mountain, as an object that resists - becomes an enemy; the climber transforms him or herself into the figure of a warrior (they learn that they are one when confronted with the properties that inhibit action and then block life functions). Antagon (the impersonal noun) recognizes this as the enemy or personification of "power" and recognizes itself as "the ice warrior". When the climber escapes with their life in a confrontation with a mountain, they realise that they are a CONQUEROR. Edmund Hillary emerged from his confrontation with the mountain not as a sports winner but as a valiant conqueror. He expressed his attitude towards the personified object of struggle by describing the mountain as a bastard - which should be understood to mean that he was dealing with a scoundrel who was knocked off or even according to another version - killed, acting together with Sherpa Tenzing Norgay. ${ }^{15}$

Individualism in the antagon does not exclude the mountain-conqueror from participation in dignified morality. The antagonist can afford a morally extraordinary act if he or she is to save someone's life. When they are about to help someone else, risking their own life, they abandon their role as a fighter and become a heroic rescuer. Not every climber can afford a supererogative act, just as not everyone can or wants to show kindness. So it is not universally true that in the environment of Himalayan mountaineering "friendship, partnership, helping is common, inscribed in what we do". ${ }^{16}$

The cynical and heartless "passing by" of a dying climber or the literal walk "by" someone in need of immediate support, which would be a case of unparalleled barbarism, is just as possible as the merciful coming to their aid on a frosty night, by crossing an ice wall - "worth" conquering for the sake of glory in the achievement. On an expedition to the Karakorum and then Everest Aleister Crowley, against the protests of his team and porters, took a large collection of books, including the New Testament and the Book of the Law, the gospel of the - new to him - Zarathustrian faith. From the first stemmed the commandment to love one's neighbour, and from the second the consent to unconditional freedom of action ("Do what you will, that is the whole Law"). And even if he took almost all the books of wisdom with him on his expedition to the Himalayas, (which he did) the beast of demonic power, the authoritarianism of a brutal team leader still came out of him, in his direct relationships during the climb itself. What Aleister Crowley - Great Beast 666 - who had "no compassion" for his dying climbing companions could not do (he did not even stop at the place where four climbers from his team died), was done gloriously by Denis Urubko - who distinguished himself with bravery, courage and sacrifice. The two Himalayan events in which the social morality of climbers was revealed with full clarity are separated by more than a century: the disgraceful first took place in 1905, and the noble second in 2018.

The ethical code of mountaineering did not yet exist in the early 20th century. It came into being as a result of mistakes and tragic errors gained in the experience of climbing. As Himalaism developed - a social movement previously unknown to mankind - in which the struggle for survival became intertwined with the struggle for individual passage to fame,

15 As the two men made their way back down, the first climber they met was teammate George Lowe, also a New Zealander. Hillary's legendary greeting: "Well, George, we knocked the bastard off!" Mount Everest was conquered for the first time on May $29,1953$.

16 This was said by Krzysztof Wielicki, the leader of the K2 expedition, in 2018 awarded the Fair Play Award for the help provided to Francis Revol by Denis Urubko and Adam Bielecki. 
each time there was a moral reframing of the feat to be compared and as a generalization to be framed as an imperative or a prohibition. The ethical code of the high-mountain climber has been inscribed in the culture of mountaineering supplemented by normative precedents. ${ }^{17}$

If the aforementioned Crowley could use the code of the Himalayan climber on the same basis as he fanatically absorbed the "holy" books with their recipe for decent conduct, he would have still appeared as a barbarian mountain conqueror - as a disgrace to the human race and to the state of the mountaineering aristocracy both at the same time (1905). And if Denis Urubko had not read the Mountain Ethics Declaration, and only learned its key rules in practice, then from the ethos of mercy and the custom of noblesse oblige - from which he derived the virtues of a warrior and probably adopted from the purity of heart and righteousness of mind of his closest relatives - then he would never have been first to step out on that frosty night, ready to save the lives of others.

The humanity of the ice warrior of the Alps and Himalayas is the goodness of the person - and as a universal virtue it is contained in neither the Mountain Ethics Declaration nor Olympism. The well-known cases of a sports competitor saving a competitor's life (a drowning person in a swimming marathon) testify that the supererogatory act is originally an intrinsically free act of willingness - resulting from participation in a culture of praiseworthy conduct. This is, however neither Olympic culture, nor Himalayan culture, but comes from a personalistic Latin civilisation - in which the commandment to respect the health and life of a person is not a moral imperative but a sacrificial duty. "In our environment we value this human element very highly," said Piotr Pustelnik, "because climbing is not only about success, not only about technique, which is complementary to it" [11]. ${ }^{18}$

However, neither Olympism nor Himalaism, in which the "game" is about life, demands the sacrifice of life for life. Both realities are conventional, and existentially unnecessary. Olympism is not salvation "through a struggle for peace", whereas Himalaism is as much about war as the conquerors of mountains are warriors. The literal existence of global mankind does not directly depend on either one. In social reality, the morality of the stadium agonist differs from that of the mountain antagonist. Agonism must be fair, which follows as a precept from the rule of fair play. The desired outcome of the agon depends on whether the fellow competitors are fair. A morally normalized agon is called sport. In the fight against an unequal opponent - imagined as a giant in the climber's antagonism - one cannot appeal to chivalric morality. The observer does not require the conqueror to participate in sporting morality, although he or she - remaining in competition with themselves - will act honourably and despise an easy victory. As was the case for Reinhold Messner who has always confirmed that he would compete with himself without assistance (oxygen, ladder, drugs, phone) [12] ${ }^{19}$ He did not enter the competition, but in absentia he still inflicted on others the standard of fairness in the crypto version.

In passing through the "gate of death" the judge does not stand waiting for the climber, as happens at the finishing line of a mountain stage of a cycling race. No one uses a red card, which would be a sign of the referee's disapproval - exposing the climber's cheating. Even more so, no one requires a Himalayan climber to participate in Olympic morality which is much more ethically sublime. In extreme cases, the conqueror-warrior compensates for the risk of death by the triumphalism of the conqueror. They declare themselves a conqueror in a book-length heroidramatic epic.

17 Its name varies although climbers themselves speak of the Mountain Ethics Declaration; the Report on the death of the Polish climbers on Broad Peak in March 2013 was prepared by reference to this code.

18 The interview given by Piotr Pustelnik in connection with the tragic deaths of two members of the Polish winter expedition on K2 [11]. 19 Messner said that "my ABC of traditional adventure climbing - no artificial oxygen, no bolts, no communications, no drugs - has been taken to an absurd level" [12]. 
The Himalayan climber is not controlled by a moderator in the person of a referee, and yet for the sake of self-respect he or she can act fairly when they enter into a contest with themselves. Towards the "opponent" - the mountain - he is an antagonist; in relation to himself, he may be an agonist - comparing themselves with themselves. The very act of climbing itself falls into the category of agon by the singularity of the vector of self-referencial causality (competition with oneself). This triggers self-enhancement of self-worth, and therefore instantly updates personal and social identity - after the result of the "out-ofbounds" act has been recognised by the social mirror of the referees [12]. ${ }^{20}$

The Olympic act is performed through honesty and friendship. Both moral goods constitute the ideological rationale for the sporting act. This means that the Olympic athlete, as the winner in the stadium, is a living sign of a participant in a righteous life. At least this is how the moral culture of Olympism - which is the communal thinking of the utopians who persistently modernise the representations of the world's nations - integrates itself particularly magnificently as an Olympic family during the Games themselves.

\section{CONCLUSIONS}

The strong-anthropic principle confirms that fine tuning has taken place in the everyday world of nature, and that without fail mankind uses it. When one destroys the community framework of life, the other comes to redeem the evil for them and to point out the path of moral righteousness. The Olympic athlete is one of many to whom the mission of renewal in humanity is entrusted by the moral leaders of humanity. The Olympic athlete must fill the stadium, summoning to himself or herself competitors and spectators, and becomes a moderator of the elders who form the judges. By this he or she becomes a real "co": a co-competitor and co-participant in the sports family, which shares the same qualities of dignity and decorum. Thanks to the moral tasks that the athlete has accepted and has to cope with - he or she becomes restorative, renewing and even redeeming - so long as they gain a deepened awareness of their destiny - to overcome evil with good. ${ }^{21}$ At this level of social reality the athlete is transformed into an ideological communitarian, becoming an activist for the Olympic Committees, a moralist of artistry, or an ethicist of Olympism.

The Himalayan climber exists by choice outside the communitarian society, which means that community could be a moral burden for him or her. They take their personal identity from the community of family and their social identity from their professional institution but dispense with them when they begin to visit the mountains as a conqueror. They exclude themselves from ideological communitarian relationships, thus foisting misfortune onto those people close to them (to them he or she is socially dead). However, they revive their social identity by choice and necessity as a member of the team, becoming an individualist in the collectively unified team. In the final phase of an expedition, they free themselves from dependence to take up the conqueror's task in their own style. The conqueror Himalayan of mountains always depends on someone; however, as a warrior he or she leads themselves alone to the fame of the conqueror. Even when ten climbers conquer the same mountain at the same time, each of them achieves the conquest individually and each is acclaimed by being named. ${ }^{22}$

In the forced structure of the collectivism of the conquest expedition, the individualistic aspirations of the primate are not concealed, which causes anxiety and arouses conflicts. The climber does not part from their loved ones so as to associate with strangers. The wedding

20 Messner added that his agonistic climbing was always one-off, unique; one can only experience the original naturalness of a mountain once (even the same mountain but climbed from the unconquered side, or the same mountain but climbed in an unknown style); Himalayan transgression is not to do 'the same thing' again (cyclicity is not part of climbing) [12]

21 I mean here the Olympic athlete as a redeemer of the moral evil of war.

22 The winter ascent of K2 on January 16, 2021, was done by 10 sherpas simultaneously. They were presented to the "world" by name and surname as individual conquerors ("together but separately"). 
ring removed for the time of the trip - a sign of pledged fidelity and constant presence ("for better or for worse") - will be replaced with the rope of the climbing brotherhood. Departing from spiritual unity with their spouse, they join a pair of soloists who calculate their own chances. In moments of losing self-control - where for example the lack of oxygen leads to swelling of the brain and, as a consequence, the loss of logical thinking - the mountaineer excludes themselves from the promised relationship of "living on a rope". The Himalayan climber is a wretch: he or she worries their relatives by approaching death or even dying prematurely. Then they remain forever in the frozen pose of a would-be philosopher of life - the unfinished drama of dying prematurely in "early and foolish youth". All too often the mountaineer ends their life as an unnecessary victim of individualistic extremism. A Himalayan climber who escapes with their life after very many years of adventurous escapism (managing to live through two or even three Olympic generations between the ages of 20 and 50) intellectualises himself literally. They are not philosophers when they draw up a philosophy of life, but rather - from a scientific point of view - provide invaluable idiographic material worthy of being transformed into a theory of the grounded case, which after its repetition becomes a metatheory of the generalised Himalayan climber.

To a Polish Nobel Prize-winning poet, he is a lost Yeti!

\author{
"Yeti, we've got Shakespeare there. \\ Yeti, we play solitaire \\ and violin. At nightfall, \\ we turn lights on, Yeti. \\ Up here it's neither moon nor earth. \\ Tears freeze. \\ Oh Yeti, semi-moonman, \\ turn back, think again!" [13] ${ }^{23}$
}

The poet asks for the presence of the extremist in the zone of life, and I understand that. For poets are there to moralise as teachers of a life of dignity. But a philosopher is an observer, not a moraliser. So the philosopher will say: Conqueror, it is good that you exist - you give me much to think about man as an extremist. And if the Himalayas were not there, humans would still reach where sight does not reach, in an enquiry into the meaning of destiny.

It leads to the conclusion at the level of the metaphysical cognition of actors of extreme life - the communal Olympic athlete and the individualistic Himalayan climber - that, although Olympism and Himalaism are disjointed as THEORIES explaining their existence, yet both are encompassed by cosmism as a cosmological episteme. This may lead to the unveiling of another mystery of metaphysical anthropology, contained in the enquiry about the man of extreme transgression in relation to the Logos of transcendence. After all, the reasoning of both participates in the Logos of the universe, through which their reasoning acquires knowledge of the sense given to it. Everyone's reasoning can arrive at the truth about the Sense entrusted to human existence [14]. ${ }^{24}$ It is, therefore, worth considering which of them - the Olympic athlete or the Himalayan climber - propels him or herself more towards that which is pre-ordained ahead of them. This applies to everyone, by the way, not only the actors of extreme exploits.

23 From a poem by Wisława Szymborska, „Notes from a Nonexistent Himalayan Expedition”, In: Calling Out to Yeti [13].

24 Joseph Ratzingier in Introduction to Christianity [14] writes about this relationship: of the human person's reasoning being situated in the Logos of the world, of human rationality being "secondary to being itself, to thought which is being itself". In turn, the cognizability of the entities of the universe is addressed by the metaphysical principle of the investigability of nature "extended to the question of the cognizability of all reality" (intelligibilitas entis); see: Michał Heller [15]. 


\section{REFERENCES}

[1] Bulletin du Comite International des Jeux Olympiques, Paris 1894, Juillet, No 1.

[2] Hezjod. Teogonia [Theogony]. Warszawa: Armoryka: Sanodmierz; 2010. Polish.

[3] Chronik - Verlag in der Harenberg Kommunikation. Dortmund: Verlags und Mediengesellschaft mbh \&Co.KG; 1990.

[4] Crouch G. The Great Ascents. Climbing's top achievements of the century, Climbing Magazine - Millenium Special Issue. 2000; No. 192:84.

[5] Isserman M. Weaver S. Fallen Giants: A History of Himalayan Mountaineering from the Age of Empire to the Age of Extremes. Yale: University Press; 2008.

[6] Coubertin P. de. Les assises philosophiques de l' Olympisme moderne. W: Pierre de Coubertin. Warszawa: PTNKF; 1994

[7] Pawłucki A. Sport, asceza i miłość [Sport, asceticism and love]. Kraków: Impuls; 2019. Polish.

[8] Coubertin P. de. La symphonie inachevée. Revue Olympique. 1976;1:99-100.

[9] Dogiel G. Metafizyka [Metaphysics]. Kraków: ITKM; 1992. Polish.

[10] Pawłucki A. Natural law and acts of extreme climbers - agonists of the mountain stadium. Balt J Health Phys Act. 2016;8(1):66-79. https://doi.org/10.29359/BJHPA.08.1.08

[11] Darada M. Piotr Pustelnik: Broad Peak a moralny kod alpinizmu [Piotr Pustelnik: Broad Peak and the moral code of mountaineering]. Dziennik Łódzki. 2013.09.19. Polish.

[12] Messner R. Über Leben. Munchen: Piper Verlag GmbH; 2014.

[13] Szymborska W. Wołanie do Yeti. Kraków: SIW Znak; 2017. Polish.

[14] Ratzingier J. Wprowadzenie do chrześcijaństwa [Introduction to Christianity]. Lublin: KUL Publishers; 2017.

[15] Heller M. Filozofia światów [Philosophy of the worlds]. Kraków: SIW Znak; 1992. Polish. 